\title{
Implikasi Hukum Kebijakan Desentralisasi dalam Hubungan Kewenangan antartingkat Pemerintahan Negara Kesatuan
}

\author{
Andi Kasmawati \\ Dosen PPKn FIS-UNM \\ Jl. A. Pangerang Petta Rani Makassar \\ kasamawatiamri@yahoo.co.id
}

\begin{abstract}
The implication of post-new era decentralization has created the dynamic of the relation between government and district government. The authority of district governmental arrangement used to be centralized in Jakarta. Now, it is decentralized in districts. The focused problem of this research: first, how is the effect of decentralization policy on the relation of governmental inter-level in a united nation? Second, how is the conflict resolution of governmental inter-level authority in a united nation? This research used the constitutional law approach and conceptive approach. The normative and empiric research are done in central and district government. The data is collected through a literacy study and interview which is analyzed qualitatively. The result of the research has showed that; first, the policy of decentralization affects has positive impact which is improvement of efficiency and effectively in conducting the government matter, and improves community participation, conversely the negative impact is conflict of authority occurs as the result of imbalanced constitutional law, the primordial and nepotism potency. Second, the authority conflict is solved by perfecting the constitution, strengthening the real autonomy, and the optimizing assistance, supervision, and evaluation.
\end{abstract}

Key words : Decentralization, united nation, and authority conflict.

\begin{abstract}
Abstrak
Penerapan desentralisasi paska Orde Baru menimbulkan dinamika hubungan antara pemerintah dengan pemerintah daerah. Kewenangan penyelenggaraan pemerintahan daerah yang tadinya terpusat di Jakarta, kini telah didesentralisaikan ke daerah-daerah. Fokus masalah dalam penelitian ini: Pertama, bagaimanakah dampak kebijakan desentralisasi terhadap hubungan kewenangan antartingkat pemerintahan negara kesatuan? Kedua, bagaimanakah penyelesaian konflik kewenangan antartingkat pemerintahan negara kesatuan? Penelitian menggunakan pendekatan perundang-undangan dan pendekatan konsep. Jenis penelitian normatif dan empirik, dilakukan pada pemerintah pusat dan daerah. Data yang diperoleh melalui studi literatur dan wawancara, dianalisis secara kualitatif . Hasil penelitian menyimpulkan; pertama, kebijakan desentralisasi berdampak positif, yaitu peningkatan efisiensi dan efektivitas penyelenggaraan urusan pemerintahan, dan peningkatan partisipasi masyarakat. Secara negatif terjadi konfik kewenangan karena perundang-undangan tidak sinkron, potensial terjadi sikap primordial dan nepotisme. Kedua, konflik kewenangan diselesaikan dengan cara penyempurnaan perundang-undangan, penguatan otonomi riil, dan optimalisasi pembinaan, pengawasan dan evaluasi.
\end{abstract}

Kata kunci : Desentralisasi, negara kesatuan, dan konflik kewenangan. 


\section{Pendahuluam}

Ketika pendiri negara (the founding fathers) menetapkan dalam konstitusi bahwa negara Indonesia adalah negara kesatuan, maka konsekuensi dari tata pemerintahan tidak boleh ada negara dalam negara atau tidak boleh ada daerah provinsi yang merasa dirinya bersifat "negara" (negara bagian), sebagaimana federasinya Amerika Serikat. ${ }^{1}$ Indonesia lebih dekat pada sendi pemerintahan Federal-like arrangement versi Kanada², di mana residual power (kekuasaan sisa), tetap ada pada pemerintah pusat sebagai ciri dari negara kesatuan.

Undang-Undang No. 32 Tahun 2004 tentang Pemerintahan Daerah merupakan penjabaran dari Pasal 18 UUD NRI Tahun 1945. Dalam undang-undang tersebut pemerintah daerah diberi otonomi yaitu: hak dan wewenang, serta kewajiban daerah otonom untuk mengatur dan mengurus sendiri urusan pemerintahan dan kepentingan masyarakat. Adanya pemerintahan daerah, menimbulkan hubungan antara pemerintah dengan pemerintah daerah, hubungan tersebut menimbulkan konsekuensi pada pembagian urusan. Pembagian urusan dapat dilakukan dengan cara desentralisasi.

Penerapan desentralisasi ini menimbulkan dinamika hubungan antara pemerintah dengan pemerintah daerah. Sebagaimana digambarkan Mackie $^{3}$ bahwa pasang surut hubungan antara pusat dan daerah sejatinya selalu mewarnai kehidupan berbangsa dan bernegara di Indonesia. Mackie lebih lanjut mengemukakan ${ }^{4}$ bahwa Otonomi Daerah yang sangat luas telah menyebabkan nuansa politik yang lebih tinggi dari pada upaya peningkatan pelayanan publik. Penyusunan organisasi perangkat daerah

${ }^{1}$ F. Isjwara. Pengantar Ilmu Politik, Bina Cipta, Bandung, 1992, hlm. 211. Federasi adalah bentuk tengah, suatu bentuk kompromistis antara konfederasi yang hubungannya tidak erat dan negara kesatuan yang kukuh ikatannya. Komponen-komponen suatu federasi menghendaki persatuan (union) tetapi menolak kesatuan. Bentuk Negara federasi (federal) adalah gejala moderen, baru dikenal sekitar tahun 1787, ketika pembentuk-pembentuk konstitusi Amerika Serikat memilih berbentuk federal sebagai bentuk pemerintahan mereka. Sejak saat inilah negara Amerika Serikat menjadi "bentuk model" dari hampir semua federasi-federasi yang dibentuk kemudian.

${ }^{2}$ C.F. Strong, Modern Political Constitutions: An Introduction to comparative study Their History and Existing. Dalam terjemahan Konstitusi-Konstitusi Politike Modern Kajian Tentang Sejarah dan Bentuk-Bentuk Konstitusi Dunia, 1966. SPA Timework. Editor, Derta Sri Widowatie dan Waluyati Handayani, Nuansa dan Nusasembada, Ujungberung, Bandung, 2004, hlm. 144. Pada pembagian kekuasaan di Kanada yang bentuk negaranya adalah negara federal. Mendefenisikan pendistribusian kekuasaan unit-unit federasi dalam konstitusi federal. Tujuannya adalah untuk memperkuat kekuasaan federal dengan mengorbankan masing-masing anggota federasi. Unit-unit federasi pada pemerintahan kanada tidak disebut dengan istilah negara bagian (states), melainkan provinsi (provinces). Dengan demikian, kekuasaan simpanan (reserve of powers) ada pada otoritas federal, maka konstitusinya lebih mendekati konstitusi negara kesatuan.

${ }^{3}$ Mackie, dalam Safri Nugraha, Eko Prasojo, Irvan Ridwan Maskun, Harsanto, Teguh Kurniawan, dan Bani Pamungkas. Pemahaman dan Sosialisasi Penyusunan RUU Tata Hubungan Kewenangan Pemerintah Pusat dan Daerah. Dikunjungi pada website Departemen Ilmu Administrasi FISIP UI, http;//www.admsci.ui.edu/ ?PID=20062007013050\&act=depublication, hlm 5-6, diakses Kamis, 12 Nopember 2007

${ }^{4}$ Mackie, Op. Cit., hlm. 7 
banyak ditentukan oleh akomodasi kepentingan tertentu, pengisian jabatan dalam struktur organisasi perangkat daerah sangat ditentukan oleh afiliasi seseorang dengan bupati atau walikota, bahkan di beberapa daerah nepotisme berdasarkan kebangsawanan, sukuisme dan afiliasi politik masih mewarnai proses rekrutmen, penempatan, promosi dan mutasi jabatan tertentu. “Gelar Kebangsawanan” secara sengaja diciptakan oleh bupati dan walikota untuk memperkuat posisi jabatan, sekaligus membedakan masyarakat biasa dengan masyarakat yang memiliki status kebangsawanan tertentu. Hal ini muncul dengan istilah "Laskar" dan "Putra Asli".

Gambaran dari sikap pemerintah daerah, beserta elit lokal inilah yang berimplikasi pada terjadinya disharmonisasi. Sebagaimana pandangan Blair dikutip Sutoro Eko, ${ }^{5}$ bahwa salah satu bahaya desentralisasi adalah desentralisasi mungkin hanya memberdayakan elit lokal, yang lebih buruk lagi mengekalkan kemiskinan dan ketimpangan.

\section{Rumusan Masalah}

Permasalahan yang dibahas dalam penelitian ini adalah, (1) bagaimanakah dampak kebijakan desentralisasi terhadap hubungan kewenangan antartingkat pemerintahan dalam negara kesatuan? (2) bagaimanakah penyelesaian konflik kewenangan antar tingkat pemerintahan dalam negara kesatuan?

\section{Tujuan Penelitian}

Adapun tujuan penelitian adalah untuk menjelaskan dan mengkaji dampak kebijakan desentralisasi terhadap hubungan kewenangan antartingkat pemerintahan dalam negara kesatuan, dan merumuskan penyelesaian konflik kewenangan antartingkat pemerintahan dalam negara kesatuan.

\section{Metode Penelitian}

Penelitian ini menggunakan pendekatan perundang-undangan dan pendekatan konsep $^{6}$ jenis penelitian normatif-sosiologis, analisis data deskriptif-analitis ${ }^{7}$

\footnotetext{
${ }^{5}$ Blair, et. al. dalam Sutoro Eko, Desentralisasii, Demokrasi Lokal dan Pembangunan Desa, diakses pada website: www.ireyogya.org/sutoro/desentralisasi_pembangunan_desa.pdf. diakses 13 Nopember 2008

${ }^{6}$ Lihat Peter Mahmud Marzuki, Penelitian Hukum, Prenada Media Group, Jakarta, 2005, hlm. 93

${ }^{7}$ Lihat Lexy J. Moleong, mengutip pendapat Bogdan dan Biklen, Metode Penelitian Kualitatif edisi revisi, PT. Remaja Rosdakarya, Bandung, 2006, hlm. 11
} 
dilaksanakan di Kantor Kementerian Dalam Negeri, Pemerintah Daerah Provinsi Sulawesi Selatan, dan Kabupaten Bone, Kabupaten Takalar, Kabupaten Tana Toraja dan Kota Makassar. Data primer diperoleh dari nara sumber melalui wawancara terstuktur dan mendalam, data sekunder yaitu data diperoleh melalui studi literatur. ${ }^{8}$ Data dianalisis dengan menggunakan teknik analisis kualitatif deskriptif dengan panduan teori dan kerangka konseptual yang telah dibuat.

\section{Hasil dan Pembahasan}

\section{Dampak Kebijakan Desentralisasi terhadap Hubungan Kewenangan antartingkat Pemerintah dalam Negara Kesatuan}

Pengaturan kewenangan pemerintahan menurut UU No. 32 Tahun 2004 tentang Pemerintahan Daerah, bila dibandingkan dengan undang-undang pemerintahan daerah sebelumnya, yaitu pada UU No. 22 Tahun 1999 kewenangan yang diserahkan oleh pemerintah secara substasi tidak berbeda. Hal yang berbeda adalah hilangnya hierarki pemerintah provinsi terhadap pemerintah daerah kabupaten dan kota. Pada UU No. 22 Tahun 1999, pelaksanaannya dipandang banyak menimbulkan berbagai masalah tidak diduga sebelumnya ${ }^{9}$ oleh karena itu UU No. 32 Tahun 2004 tentang Pemerintahan Daerah mengatur kembali hierarki tersebut. Sebagaimana dikemukakan Jimly Asshiddiqie ${ }^{10}$ yaitu:

"Dalam hal pengaturan mengenai pembagian wilayah materi UU No. 32 Tahun 2004 ini dapat dikatakan sama dengan UU No. 22 Tahun 1999. Akan tetapi, hubungan antara pemerintah pusat, provinsi dan kabupaten/kota diatur tidak lagi seperti yang terdapat dalam UU No. 22 Tahun 1999 tentang Pemerintahan Daerah. Ketentuan UU No. 22 Tahun 1999, gubernur dan bupati/walikota tidak memiliki hubungan hirarkis satu dengan yang lain, sedangkan menurut versi UU No. 32 Tahun 2004 tentang pemerintahan daerah sebaliknya."

${ }^{8}$ Lihat Soerjono Soekanto dan Sri Mamuji. Penelitian Hukum Normatif, Suatu Tinjauan Singkat, PT.Raja Grafindo Persada, Jakarta 2006, hlm. 24

${ }^{9}$ Lihat Moh. Mahfud MD., Membangun Politik. Hukum Menegakekan Konstitusi, Pustaka LP3ES Indonesia, Jakarta, 2006, hlm. 228. Seperti semakin mudahnya oknum DPRD ikut melakukan KKN, Mahfud mengutip pendapat Abdul Gaffar Karim, 2003 dalam Pengantar Buku Kompleksitas Persoalan Otonomi Daerah di Indonesia, disebutkan ada sepuluh masalah atau kompleksitas yang timbul dari UU No. 22 Tahun 1999, diantaranya yaitu: 1) Posisi DPRD menjadi sangat kuat, (lembaga ini bukan lagi menjadi bagian dari pemerintah daerah melainkan menjadi lembaga legislatif daerah yang sejajar dengan (dan dapat meminta, menerima, menolak, dan menjatuhkan mosi kepada) Kepala Daerah). 2) Anggota-anggota DPRD tidak dapat di recall, 3) Kewenangannya sangat kuat karena lembaga inilah yang memilih secara final kepala daerah untuk kemudian mengawasi, 4) Meminta Laporan Pertanggungjawaban, 5) Dapat menjatuhkan Kepala Daerah.

${ }^{10}$ Jimly Asshiddiqie, Pokok-Pokok. Hukum Tata Negara Indonesia Pasca Reformasi, Buana Ilmu Populer, Jakarta Barat, 2007, hlm. 409. 
Kemudian Moh. Mahfud MD ${ }^{11}$ juga mempertegas bahwa dalam hal prinsip otonomi ini, UU No. 32 Tahun 2004, menganut prinsip yang sama dengan UU No. 22 Tahun 1999, yakni otonomi luas dalam rangka demokratisasi. Prinsip otonomi luas itu mendapat landasannya pada Pasal 18 UUD NRI Tahun 1945 dan memperhatikan kompleksitas yang muncul dilapangan antara pemerintah provinsi dan pemerintah kabupaten/kota, maka UU No. 32 Tahun 2004 ini menyambung kembali hubungan hierarkis antara pemerintah provinsi dan pemerintah kabupaten/ kota meski dalam UU itu tak secara eksplisit menyebutnya dengan tegas. Itu bisa dilihat, misalnya dalam hal penyampaian Laporan Keterangan Pertanggungjawaban (LKPj) Kepala daerah kepada pemerintah pusat yang harus disampaikan secara berjenjang."

Perbedaan lainnya antara UU No. 32 Tahun 2004 dengan UU No. 22 Tahun 1999 tentang Pemerintahan Daerah adalah pada penggunaan istilah kewenangan pada UU No. 22 Tahun 1999, berubah menjadi urusan pada UU No. 32 Tahun 2004. Pada perubahan tersebut lebih menekankan pada apa yang hendak diserahkan secara operasional, yaitu urusan pemerintahan, pada penyerahan urusan itulah menimbulkan kewenangan bagi pemerintah daerah untuk menjalankan urusan yang lebih lanjut diatur dalam peraturan perundang-undangan termasuk peraturan daerah.

Pembagian urusan ini menunjukkan bahwa pada UU No. 32 Tahun 2004, menganut paham General Competence atau open end arrangement. ${ }^{12}$ Sebagaimana dikemukakan Hanif Nurcholis: ${ }^{13}$

"Cara penyerahan General Competence inilah yang dianut oleh UU No. 22 Tahun 1999 dan UU No. 32 Tahun 2004. Pasal 7 ayat (9) dan ayat (2) UU No. 22 Tahun 1999 menjelaskan bahwa: Kewenangan daerah mencakup kewenangan dalam seluruh bidang pemerintahan, kecuali kewenangan dalam bidang politik luar negeri, pertahanan keamanan, peradilan, moneter dan fiskal, serta agama. Kewenangan bidang lain meliputi kebijakan tentang perencanaan nasional dan pengendalian pembangunan nasional secara makro, dan perimbangan keuangan,

\footnotetext{
${ }^{11}$ Moh. Machfud MD., Op. Cit., hlm. 233.

${ }^{12}$ Lihat Hanif Nurcholis, Teori dan Praktek Pemerintahan dan Otonomi Daerah, Grasindo, Jakarta, 2005, hlm. 155-156 "Penyerahan wewenang pemerintahan oleh pemerintah pusat kepada daerah dapat dilakukan dengan dua cara yaitu: 1) Ultra vires doctrine yaitu pemerintah pusat menyerahkan kewenangan pemerintahan kepada daerah otonom dengan merinci sartu persatu. Daerah otonom hanya boleh menyelenggarakan wewenang yang diserahkan tersebut. Sisa kewenangan dari kewenangan yang diserahkan kepada daerah otonom secara terperinci tersebut tetap menjadi kewenangan pemerintah pusat. Cara penyerahan kewenangan inilah yang dianut UU No. 5 Tahun 1974. 2) open end arrangement atau General Competence yaitu daerah otonom boleh menyelenggarakan semua urusan diluar yang dimiliki pusat. Artinya pusat menyerahkan kewenangan pemerintahan kepada daerah untuk menyelenggarakan kewenangan berdasarkan kebutuhan dan inisiatifnya sendiri diluar kewenangan yang dimiliki pusat. Disini pusat tidak menjelaskan secara spesifik kewenangan apasaja yang diserahkan ke daerah tetapi hanya menyatakan, "Diluar kewenangan pusat semuanya adalah kewenangan daerah".

${ }^{13}$ Ibid., hlm. 157.
} 
sistem administrasi negara dan lembaga perekonomian negara, pembinaan dan pemberdayaan sumber daya manusia, pendayagunaan sumber daya alam serta teknologi tinggi yang strategis, konservasi, dan standarisasi nasional. Dengan demikian semua kewenangan diluar yang disebutkan adalah kewenangan daerah. Sedangkan pada UU No. 32 Tahun 2004 sebagai penyempurnaan UU No. 22 Tahun 1999 juga menganut open end arrangement atau General Competence tersebut dalam UU ini yang menjadi kewenangan pemerintah pusat adalah: Politik luar negeri, pertahanan, keamanan, yustisi, moneter dan fiskal nasional, dan agama."

Berdasarkan uraian tersebut dapat disimpulkan bahwa cara penyerahan kewenangan tersebut merupakan gabungan antara Ultra vires doctrine dan open end arrangement atau General Competence.

Dampak positif kebijakan desentralisasi terhadap hubungan kewenangan antartingkat pemerintahan negara kesatuan.

Desentralisasi meningkatkan efisiensi dan efektivitas penyelenggaraan pemerintahan.

Efektivitas dan efisiensi penyelenggaraan pemeritahan dicapai dengan menerapkan program pelayanan terpadu dan program pelayanan gratis pada beberapa urusan atau keperluan masyarakat, hal ini menunjukkan adanya efisiensi dan efektivitas pelayanan kepada masyarakat, sebagaimana diterapkan pada pemerintah Provinsi SulawesiSelatan, Kota Makassar, dan Kabupaten Takalar, Tana Toraja, dan Bone.

Desentralisasi meningkatkan partisipasi masyarakat dalam pemerintahan dan Pembangunan Daerah

Peningkatan partisipasi masyarakat dalam penyelenggaraan pemerintahan, pada dasarnya sudah berjalan dengan baik, khususnya bidang politik, namun dalam hal pemberdayaan belum dapat memenuhui sendi-sendi otonomi daerah, yang ditandai dengan terbukanya peluang bagi masyarakat untuk berpartisipasi dalam bidang politik, seperti hak untuk dipilih dan memilih dalam pemilihan legislatif maupun pemilihan kepala daerah, sedangkan dalam hal pemenuhan hak-hak rakyat belum dapat terpenuhi dengan baik.

Dampak negatif kebijakan desentralisasi terhadap hubungan kewenangan antartingkat pemerintahan negara kesatuan.

\section{Konflik Kewenangan antara Pemerintah dan Pemerintah Daerah}

Adanya kewenangan yang dimiliki oleh pemerintah daerah dalam menjalankan urusan pemerintahan merupakan penyerahan atau pendelegasian urusan oleh 
pemerintah, dengan menggunakan teori "Perolehan Kekuasaan" (bevogdheidsverkijging) yaitu: 1. Pengakuan Kekuasaan (Attributie) dan 2. Pelimpahan Kekuasaan (Overdracht)" ${ }^{14}$

Hasil penelitian baik pada tingkat pemerintah (Kementerian Dalam Negeri) maupun pemerintah daerah provinsi (Provinsi Sulawesi Selatan) dan beberapa pemerintah daerah kabupaten/kota (Kota Makassar, Kabupaten Takalar, Kabupaten Tana Toraja, dan Kabupaten Bone), serta dari berbagai sumber literatur, ternyata ada beberapa urusan yang berpotensi melahirkan konflik kewenangan, berdasarkan wawancara Kepala Seksi Urusan Penanaman Modal, Badan Usaha Milik Negara, Tenaga Kerja dan Transmigrasi Kementerian Dalam Negeri ${ }^{15}$ mengemukakan bahwa: “Konflik kewenangan antara pemerintah dengan pemerintah daerah pada dasarnya dapat terjadi pada semua jenis urusan yang telah diserhkan kepada pemerintah daerah, baik pada pemerintah daerah provinsi maupun pemerintah daerah kabupaten/ kota, namun konflik kewenangan yang sering terjadi diantaranya adalah: Urusan Pertanahan, Pertambangan, Tenaga Kerja Asing, Perhubungan, Penanaman Modal, dan BKKBN".

Konflik kewenangan yang dikemukakan tersebut dapat kita lihat uraiannya pada tabel berikut:

Tabel 1

Konflik Kewenangan Antara Pemerintah dengan Pemerintah Daerah Berdasarkan Urusan

\begin{tabular}{|c|c|c|}
\hline $\mathrm{No}$ & Urusan & Bentuk Konflik Kewenangan \\
\hline 1 & Pertanahan & $\begin{array}{l}\text { Urusan Pertanahan yang telah menjadi urusan pemerintah daerah } \\
\text { sebagaimana diatur dalam UU No. } 32 \text { Tahun } 2004 \text { jo UU No. } 12 \text { Tahun } \\
2008 \text { tentang Pemerintahan Daerah, namun masih tetap dikelola atau } \\
\text { dilaksanakan oleh pemerintah dengan mempertahankan Badan } \\
\text { Pertanahan Nasional. }\end{array}$ \\
\hline 2 & Pertambangan & $\begin{array}{l}\text { Urusan pertambangan yang sering terjadi konflik antara pemerintah } \\
\text { dengan pemerintah daerah melalui sektor atau unit kerja, seperti tambang } \\
\text { yang ada diwilanyah hutan, maka untuk mengelola tambang tersebut } \\
\text { selain harus melalui kementerian pertambangan juga melalui kementerian } \\
\text { kehutanan, demikian pula dengan Badan Pertanahan, dan bila dikaji lagi } \\
\text { peruntukan penambangan tersebut, maka harus pula melalui Unit } \\
\text { prasarana umum. Selain itu masalah pertambangan juga sering terjadi } \\
\text { konflik antara pemerintah daerah dengan pengelola pertambangan karena } \\
\text { pengelola pertambangan terkadang tidak melibatkan pemerintah daerah } \\
\text { dalam menetapkan kebijakan pertambangan. }\end{array}$ \\
\hline
\end{tabular}

${ }^{14}$ Soewoto, "Otonomi Daerah Suatu Kajian Historik, Teoritik dan Yuridik Pelimpahan Kekuasaan Kepada Daerah", Yudika Majalah Fakultas Hukum Unair Surabaya, 1990, hlm. 275.

${ }^{15}$ Kepala Seksi Urusan Penanaman Modal, BUMN, Tenaga Kerja dan Transmigrasi, Direktorat Urusan Pemerintahan Daerah, Dirjen Otonomi Daearah, Kementerian Dalam Negeri, wawancara tanggal 19 Agustus 2009 di Jakarta. 


\begin{tabular}{|c|c|c|}
\hline 3 & $\begin{array}{l}\text { Tenaga Kerja } \\
\text { (Tenaga Kerja } \\
\text { Asing) }\end{array}$ & $\begin{array}{l}\text { Urusan tenaga kerja dalam UU No. } 32 \text { Tahun } 2004 \text { pada Pasal } 13 \text { ayat (1) Urusan } \\
\text { wajib yang menjadi kewenangan pemerintahan daerah provinsi merupakan } \\
\text { urusan dalam skala provinsi, dan pada huruf h pelayanan bidang ketenagakerjaan } \\
\text { lintas kabupaten/kota, dan pada Pasal } 14 \text { ayat (1) Urusan wajib yang menjadi } \\
\text { kewenangan pemerintahan daerah Kab./Kota merupakan urusan dalam skala } \\
\text { Kabupaten/Kota. Jadi berdasarkan perundang-undangan urusan ketenagakerjan } \\
\text { sudah menjadi urusan pemerintah daerah, namun dalam penanganan tenagakerja } \\
\text { asing menurut PP } 92 \text { Tahun } 2000 \text { tentang Tarif atas Jenis Penerimaan Negara } \\
\text { Bukan Pajak (PNBK) yang berlaku pada Departemen Tenaga Kerja dan } \\
\text { Taransmigrasi, dicantumkan bahwa setiap orang asing yang bekerja di Indonesia } \\
\text { diharuskan membanyar \$ } 100 \text { setiap bulan dan dimasukkan ke kas negara. } \\
\text { Sedangkan tenaga kerja asing ini bekerja di wilayah pemerintah daerah kab./ } \\
\text { kota, namun pemerintah daerah kab,/kota tidak mendapatkan apa-apa dari } \\
\text { tenagakerja asing tersebut, inilah yang terkadang pemerintah daerah membuat } \\
\text { PERDA tersendiri untuk mengatur masalah tenaga kerja asing. }\end{array}$ \\
\hline 4 & Perhubungan & $\begin{array}{l}\text { Dalam penyediaan sarana dan prasarana umum, urusan perhubungan juga } \\
\text { sudah diserahkan kepada pemerintah daerah baik provinsi maupun } \\
\text { kabupaten/kota, namun dalam pelaksanaannya, pemerintah daerah masih } \\
\text { memerlukan izin dari pamerintah untuk menjalankannya, sebagai contoh: } \\
\text { dalam pembuatan jembatan di Kab. Siak Provinsi Riau, izin yang diberikan } \\
\text { oleh Pemerintah, jembatan tersebut setinggi } 32 \mathrm{~m} \text { di atas permukaan laut, } \\
\text { tapi berdasarkan peraturan daerah Kab. Siak ditetapkan tinggi jembatan hanya } \\
24 \text { m di atas permukaan laut, dalam hal ini pemerintah Kab. Siak seharusnya } \\
\text { melaksankan peraturan yang telah dibuatnya sebagai kewenangan untuk } \\
\text { menentukan dan menjalankan peraturan yang telah dibuatnya berdasarkan } \\
\text { pertimbangan-pertimbangan yang ada, namun atas pertimbangan pemerintah } \\
\text { jembatan Siak tersebut dibuat dengan ketinggian } 32 \mathrm{~m} \text { di atas permukaan } \\
\text { laut. }\end{array}$ \\
\hline 5 & $\begin{array}{l}\text { Penanaman } \\
\text { Modal }\end{array}$ & $\begin{array}{l}\text { Pada urusan Penanaman Modal harusnya sudah menjadi kewenangan } \\
\text { pemerintah daerah berdasarkan UU No. } 32 \text { Tahun } 2004 \text { jo. UU No. } 12 \text { Tahun } \\
2008 \text { tentang Pemerintahan Daerah, yang ditindak lanjuti dengan lahirnya UU } \\
\text { No. } 25 \text { Tahun } 2007 \text { tentang Penanaman Modal, pada UU Penanaman Modal ini } \\
\text { Pasal } 30 \text { ayat (2) diatur bahwa Pemerintah Daerah menyelenggarakan urusan } \\
\text { penanaman modal yang menjadi kewenangannya, kecuali urusan-urusan } \\
\text { penyelenggaraan penanaman modal yang menjadi urusan Pemerintah dari } \\
\text { ketentuan pasal ini menunjukkan bahwa pemerintah tetap menjalankan atau } \\
\text { mengurus urusan penanaman modal meskipun dalam UU pemerintahan darah } \\
\text { telah mengatur bahwa urusan tersebut telah diserahkan kepada pemerintah } \\
\text { daerah (Pasal } 13 \text { dan Pasal } 14 \text { UU No. } 32 \text { Tahun } 2004 \text { tentang Pemerintah Daerah). }\end{array}$ \\
\hline 6 & $\begin{array}{l}\text { Badan } \\
\text { Koordinasi } \\
\text { Keluarga } \\
\text { Berencana } \\
\text { (BKKBN) }\end{array}$ & $\begin{array}{l}\text { Pada urusan BKKBN, lembaga ini menjadi lembaga yang berada di luar kementerian } \\
\text { negara, berdiri sebagai lembaga independen mulai dari pemerintah pusat hingga } \\
\text { provinsi, sedangkan pada tingkat kabupaten/kota BKKBN dan Keluarga Sejahtera } \\
\text { kabupaten/kota sudah difusi masuk ke pemerintah daerah, tidak lagi berdiri sendiri } \\
\text { di luar lingkup pemerintahan daerah dan berada dalam hierarki BKKBN provinsi, } \\
\text { kondisi kelembagaan ini memungkinkan terjadi konfik dan kebingungan } \\
\text { penanganan urusan BKKBN dan Keluarga Sejahtera termasuk mengkoordinasikan, } \\
\text { membina, dan mengawasi penyelenggaraan urusan yang diserahkan kepada } \\
\text { pemerintah daerah yang berkaitan dengan BKKBN dan Keluarga sejahtera, karena } \\
\text { tidakjelasnya pengaturan kelembagaan ini. Penangan urusan BKKBN dan Keluarga } \\
\text { Sejahtera tidak jelas dan mekanisme administrasinya menjadi rumit. }\end{array}$ \\
\hline
\end{tabular}

Sumber: Data Sekunder Direktorat Jenderal Otonomi Daerah 19 Agustus 2009 
Pada pemerintah daerah, di lokasi penelitian terdapat kesamaan pandangan berkaitan dengan kebijakan desentralisasi, "secara kontekstual desentralisasi dipahami sebagai suatu kewenangan mutlak dalam menjalankan urusan yang telah diserahkan oleh pemerintah kepada pemerintah daerah, sesuai UU No. 32 Tahun 2004 tentang Pemerintahan Daerah, namun pelaksaan pembagian urusan tersebut tidak terlaksana berdasarkan undang-undang, karena pemerintah pusat masih menjalankan urusan yang telah diserahkan kepada pemerintah daerah" inilah yang menimbulkan konflik.

Sejatinya urusan yang telah diserahkan pemerintah kepada pemerintah daerah bila dikaitkan dengan teori desentralisasi yang dibangun oleh Rondinelli dan Cheema ${ }^{16}$ yaitu desentralisasi adalah "the transfer of planning, decision-making, or administrative autority from central government to its field organisation, local adminstrative units, semi autonomous and parastatal organisation, local government, or non-governmant organisations". Berdasarkan teori ini pemerintah daerahlah yang merencanakan secara mandiri apa yang hendak dilaksanakan terhadap urusan yang telah diserahkan. Namun hal ini sulit dilaksankan karena pemerintah daerah harus berpedoman pada, norma, standar, prosedur, dan kriteria yang telah dibuat oleh pemerintah (pusat), dengan demikian pemerintahan daerah yang dilandasi oleh UU No. 32 Tahun 2004 tentang Pemerintahan Daerah dan berbagai peraturan perundang-undangan sebagai peraturan pelaksanaan menunjukkan terjadinya resentralisasi. Sehingga masalah desentralisasi dalam penyelenggaraan pemerintahan sebagai wujud penyerahan kewenangan dari pemerintah kepada pemerintah tidak terlaksana secara optimal.

\section{Sikap Primordialisme pada Pemerintahan Daerah.}

Sikap primordialisme yang sempit dan kaku dalam menjalankan pemerintahan tidak terjadi dalam penyelenggaraan pemerintahan daerah, namun tidak dapat dipungkiri bahwa sikap primordialisme, dapat muncul dalam kehidupan penyelenggaraan pemerintahan sesuai kondisi dan situasi masyarakat masingmasing di daerah.

\section{Sikap Nepotisme Pada Pemerintahan Daerah}

Penyelenggaraan pemerintahan, berdasarkan kebijakan desentralisasi dan otonomi daerah dapat menimbulkan sikap nepotisme, bahkan lebih jauh lagi

${ }^{16}$ Cheema G. Shabbir dan Dennis A. Rondinelli (ed), Decentralization and Development, Policy Implementation in Developing Countries, Sage Publication, Bavarly Hills, London/New Delhi, 1983, hlm. 18. 
memunculkan kolusi dan kurupsi, hal tersebut diperkuat oleh data yang peneliti peroleh dari berbagi sumber diantaranya adalah: Pertama, kasus nepotisme pada penerimaan calon pegawai negeri sipil (CPNS) di Kabupaten Simalungun Tahun Anggaran 2005 dengan tersangka Sekertaris Daerah dan Kepala Badan Kepegawaian Daerah Kabupaten Simalungun, pada kasus ini pemerintah daerah dituduhkan melanggar Pasal 5 jo. Pasal 21 dan Pasal 22 UU No. 28 Tahun 1999 tentang Penyelenggaraan Negara yang Bersih dan Bebas dari Kolusi, Korupsi, dan Nepotisme. ${ }^{17}$ Kedua, kasus nepotisme pada pemerintah kota Banjarmasin, terkait penempatan/ penujukan 2 (dua) orang kerabat/keluarga Gubernur Kalimantan Selatan pada posisi masing-masing sebagai komisaris dan direktur PT. Ambapers, Perusahaan Patungan Perusahaan Daerah PELINDO III, sebagaimana dilaporkan Forum Lintas LSM/OKP, yang oleh Forum Lintas LSM/OKP menilai penempatan/penunjukan kedua kerabat Gubernur tersebut sarat dengan nepotisme, dan penunjukannya tidak melalui surat keputusan gubernur, dan dalam menjalankan perusahan kedua pejabat tersebut telah mencairkan dana sebesar Rp. 2.000.000.000-, (dua milyar rupiah) untuk keperluan PT. Ambapers. Namun setelah bergulirnya kasus ini kedua kerabat gubernur tersebut mengundurkan diri, komisaris mundur pada tanggal 14 Juli 2004, sedangkan direktur PT. Ambapers mundur 16 Juli 2004. ${ }^{18}$

\section{Penyelesaian Konflik Kewenangan antar tingkat Pemerintahan dalam Negara Kesatuan}

\section{Pembenahan Peraturan Perundang-undangan yang Kontradiktif}

Peraturan perundang-undangan mulai dari UUD NRI Tahun 1945 yang meletakkan dasar-dasar pembentukan pemerintahan daerah, sampai kepada Peraturan Daerah yang secara teknis operasional mengatur urusan yang menjadi kewenangan masing-masing daerah, masih ditemukan ketidakkonsistenan seperti pada UU No. 32 Tahun 2004 tentang Pemerintahan Daerah sudah merinci urusan yang telah menjadi kewenangan pemerintahan baik pada pemerintah pusat maupun pada pemerintah daerah, namun pada Peraturan Menteri No. 13 Tahun 2006 tentang Pedoman Teknis Kewenangan Daerah, kemudian lahir Peraturan Menteri Dalam Negeri No. 59 Tahun 2007 tentang Kewenangan Daerah, ini menjadi acuan pemerintah daerah provinsi, kabupaten dan kota termasuk tenaga pengawas, yang

\footnotetext{
${ }^{17}$ Diakses melalui web.site. http/m.hariansib.com senin 19 April 2010

${ }^{18}$ Diakses melalui web.site. http/m.hariansib.com senin 19 April 2010
} 
materinya meniadakan kewenangan pemerintah daerah yang telah diatur dalam undang-undang yang lebih tinggi tersebut.

Pada kasus yang dipaparkan pada tabel 1, dari 6 kasus yang dikemukakan, semua konflik kewenangan yang terjadi bermuara pada peraturan yang tidak konsisten, dan dari berbagai kasus tersebut ada yang tetap berjalan sesuai kebijakan pemerintah pusat dan ada yang diselesaikan dengan merubah peraturan tersebut dengan melakukan revisi, dan ada yang diselesaiakan melalui pengadilan.

Sebagai contoh Perda yang dibatalkan karena Perda tersebut mengurus urusan pemerintahan yang dinilai oleh pemerintah bertentangan dengan peraturan perundang-undangan yang lebih tinggi, yang mengatur kewenangan untuk mengurus urusan pemerintahan sedangkan pemerintah daerah mengaturnya dalam Perda. Misalnya:

Pertama, Perda Kota Bengkulu No. 11 Tahun 2002 tentang Retribusi Izin Pengesahan Akta dan Daftar Ulang Koperasi, dibatalkan karena Pengesahan dan persetujuan badan hukum koperasi merupakan kewenangan pemerintah pusat sesuai Pasal 2 ayat (3) angka 24 huruf b PP No. 25 Tahun 2000 tentang Kewenangan Provinsi sebagai Daerah Otonom.

Kedua, PERDA Provinsi Jawa Tengah No. 14 Tahun 2003 tentang Retribusi Penyelenggaraan Perhubungan dan Telekomunikasi, dibatalkan karena berdasarkan Pasal 11 UU No. 36 Tahun 1999 tentang Telekomunikasi yang menyatakan bahwa penyelenggaraan telekomunikasi dapat diselenggarakan setelah mendapat izin dari menteri, kemudian pada Pasal 59 dan Pasal 62 PP No. 52 Tahun 1999 tentang Penyelenggaraan Telekomunikasi, pemberian izin Amatir Radio dan Izin Komunikasi Radio, TV siaran merupakan kewenangan Pemerintah Pusat.

Peraturan Perundang-undangan yang berkaitan dengan penyelenggaraan pemerintahan daerah ditemukan ketidak konsistenan dalam mengatur urusan pemerintahan, terjadi pertentangan antara satu dengan yang lainnya, kondisi inilah yang melahirkan konflik, dan kebingungan menjalankan urusan pemerintahan.

\section{Penguatan Otonomi Riil}

Selain penataan perundang-undangan yang kontradiktif, penyelesaian konflik yang ideal lainnya yang dapat dijadikan solusi terjadinya konflik kewenangan adalah penguatan otonomi Rill (rumah tangga rill). Sarundajang ${ }^{19}$ mengemukakan :

${ }^{19}$ SH Sarundajang. dalam Hamzah "Hubungan Eksekutif dengan Legislatif Daerah dan Implementasi Hukumnya". Disertasi Pascaserjana UNHAS, Makassar, 2008, hlm. 158-160. 
"berbagai jenis otonomi yang dapat digunakan dalam menjalankan otonomi daerah yaitu: 1. Otonomi Organik (rumah tangga organik), 2. Otonomi Formal (rumah tangga Formal), 3. Otonomi Materill (rumah tangga Materill/subtansif), 4. Otonomi riil (rumah tangga riil), 5. Otonomi nyata,bertanggung jawab dan dinamis.

Rasionalitas otonomi riil ini dari segi efektivitas dan efesiensi penyelenggaraan pemerintah daerah, karena dengan otonomi Riil pemerintah terfokus pada urusan atau kewenangan yang telah diserahkan dan dijalankan berdasrkan kemampuan daerahnya. Dengan kata lain, pemerintah daerah menjalankan urusan yang menjadi kewenangan berdasarkan kebijakan desentralisasi sesuai potensinya, sebagaimana teori Ajaran Rumah Tangga Riil ini suatu daerah otonom yang mempunyai potensi lebih besar, menjalankan urusan dan tugas yang diemban bisa lebih besar pula, demikian pula sebalinya daerah yang potensinya kurang maka, urusan atau tugas yang diemban juga kurang.

\section{Peningkatan Pembinaan, Pengawasan, dan Evalusi Kinerja Penyelenggaraan Urusan Pemerintahan Daerah}

Pembinaan, pengawasan, dan evaluasi kinerja penyelenggaraan urusan pemerintahan Daerah yang dilaksanakan oleh pemerintah sesuai susunan pemerintahan berpedoman pada peraturan perundang-undangan yaitu: UU No. 32 Tahun 2004. tentang Pemerintahan Daerah, Peraturan Pemerintah No. 79 Tahun 2005 Tetang Pedoman Pembinaan dan Pengawasan Penyelenggaraan Pemerintahan Daerah, serta Peraturan Pemerintah No. 6 Tahun 2008 Tentang Pedoman Evaluasi Penyelenggaraan urusan Pemerintahan daerah.

\section{Pembinaan Penyelenggaraan Urusan Pemerintahan Daerah}

Pelaksanaan pembinaan oleh pemerintah maupun pemerintah daerah provinsi masih sangat kurang dan tidak intensif. Selain itu, pelaksanaan pembinaan terkadang tidak sesuai dengan kebutuhan dan kondisi daerah, dan tidak dilaksanakan secara sungguh-sungguh. Pembinaan yang dilakukan pemerintah terhadap pemerintah daerah atau antarsusunan pemerintahan belum berjalan sebagaimana yang diharapkan, sebagaimana dikemukakan oleh Direktur Urusan Pemerintahan Daerah, Direktorat Jenderal Otonomi Daerah Kementerian Dalam Negeri: ${ }^{20}$ "Yang

${ }^{20}$ Direktur Urusan Pemerintahan Daerah, Direktorat Jenderal Otonomi Daerah Kementerian Dalam Negeri (wawancara tanggal 3 juni 2009) di Jakarta. 
melaksanakan pembinaan adalah presiden dalam hal ini Kementerian Dalam Negeri, jadi pemerintah daerah bertanggungjawab kepada presiden."

\section{Pengawasan Penyelenggaraan Urusan Pemerintahan Daerah}

Pengawasan yang dilakukan oleh pihak yang berwenang terhadap penyelenggaraan urusan pemerintahan daerah dilaksanakan dengan baik, dilaksanakan secara intensif sesuai pedoman pengawasan, hanya terkadang solusi terhadap permasalah yang ditemukan tidak segera disampaikan kepada pemerintah daerah, dan yang menjadi kendala dalam penyelenggaraan pengawasan adalah terkadang pengawas datang tiba-tiba atau mendesak sehingga pemerintah daerah kabupaten belum mempersiapkan bahan-bahan pengawasan, oleh karena itu diperlukan sosialisasi dan koordinasi yang baik dari tim pengawas.

\section{Evaluasi Kinerja Penyelenggaraan Urusan Pemerintahan Daerah}

Pelaksanaan evaluasi terhadap kinerja pemerintah daerah sesuai urusan yang telah diserahkan dilaksanakan dengan baik, namun tidak menutup kemungkinan ditemukan kendala dalam melaksanakan evaluasi seperti ketidak siapan pemerintah daerah apalagi dengan diterapkannya peraturan pemerintah yang baru mengenai mekanisme pedoman melaksanaan evaluasi penyelenggaraan pemerintahan daerah yaitu PP No. 6 Tahun 2008 tentang Pedoman Evaluasi Penyelenggaraan Pemerintahaan Daerah.

Berdasarkan data yang ditemukan bahwa penyelesaian konflik kewenangan dalam mengurus urusan yang telah dibagi antara pemerintah dengan pemerintah daerah, diselesaikan dengan cara: Pertama, melakukan koordinasi dari kedua belah pihak dalam rangka menyatukan pendapat dan menetapkan siapa yang berwenang terhadap urusan yang diperebutkan. Kedua, melalui pengadilan sesuai jenis urusan atau kewenangan yang menimbulkan konflik. Melalui Mahkamah Konstitusi, apabila konflik tersebut tidak dapat diselesaiakan dengan koordiansi. dan konflik diakibatkan karena peraturan perundang-undangan.

\section{Penutup}

Pertama, kebijakan desentralisasi dalam hubungan kewenangan antartingkat pemerintahan negara kesatuan, berdampak secara positif yaitu terjadi peningkatan efisiensi dan efektivitas penyelenggaraan urusan pemerintahan, dan peningkatan 
partisipasi masyarakat, terutama pada bidang politik. Secara negatif terjadi konflik kewenangan antartingkat pemerintahan, karena perundang-undangan tidak sinkron atau overlap, muncul sikap primordialisme dan nepotiseme sebagai konsekuensi dukung mendukung pada pemilihan kepala daerah.

Kedua, penyelesaian konflik kewenangan antartingkat pemerintahan, dilakukan dengan cara penyempurnaan perundang-undangan yang kontradiktif, penguatan otonomi riil, dan optimalisasi pembinaan, pengawasan, dan evaluasi.

\section{Daftar Pustaka}

Asshiddiqie, Jimly, Pokok-Pokok Hukum Tata Negara Indonesia Pasca Revormas, Buana Ilmu Populer, Jakarta Barat, 2007.

G. Shabbir, Cheema dan Dennis A. Rondinelli, ed., Decentralization and Development, Policy Implementation in Developing Countries, Sage Publication, Bavarly Hills, London/New Delhi, 1983.

Eko, Sutoro, Desentralisasii, Demokrasi lokal dan pembangunan Desa, diakses pada website: www.ireyogya.org/sutoro/desentralisasi_pembangunan_desa.pdf. diakses 13 Nopember 2008

I., Isjwara, Pengantar Ilmu Politik, Bina Cipta, Bandung, 1999.

Koirudin, Sketsa Kebijakan Desentralisasi Di Indonesia Format Masa Depan Otonomi Menuju Kemandirian Daerah, Avrroes Press, Malang, 2005.

Peter Mahmud, Marzuki, Penelitian Hukum, Prenada Media Group, Jakarta, 2005.

Mahfud M.D., Moh., Membangun Poltik Hukum Menegakkan Konstitusi, LP3ES, Jakarta, 2006.

, Poltik Hukum Di indonesia, LP3ES, Jakarta, 1998.

Demokrasi dan Konstitusi di Indonesia, Studi Tentang Interaksi Politik dan Kehidupan Ketatanegaraan, Liberty, Yogyakarta, 1993.

Lexy J., Moleong, Metodologi Penelitian Kuantitatif, Remaja Rosdakarya, Bandung, 2006.

Hanif, Nurtcholis, Teori dan Praktek Pemerintahan dan Otonomi Daerah, Grasindo, Jakarta, 2005.

Safri, Nugraha, et. al, Pemahaman dan Sosialisasi Penyusunan RUU Tata Hubungan Kewenangan Pemerintah Pusat dan Daearah. Dikunjungi pada website Departemen Ilmu Administrasi FISIP UI, http;/ / www.admsci.ui.edu/ ?PID=20062007013050\&act=depublication, hlm 5-6, diakses Kamis, 12 Nopember 2007

Soerjono, Soekanto dan Sri Mamudji, Penelitian Hukum Normatif, Suatu Tinjauan Singkat, Raja Grafindo Persada, Jakarta, 2006. 
Soewoto, "Otonomi Daerah Suatu Kajian Historik, Teoritik dan Yuridik Pelimpahan Kekuasaan Kepada Daerah", Yudika Majalah Fakultas Hukum Unair, 1990.

Strong, C. F., Modern Political Constitutions: An Introduction to comparative study Their History and Existing. Dalam terjemahan Konstitusi-Konstitusi Politik Modern Kajian Tentang Sejarah dan Bentuk-Bentuk Konstitusi Dunia. 1966. SPA Timework. Editor: Derta Sri Widowatie dan Waluyati Handayani, Nuansa dan Nusasembada, Ujungberung, Bandung. 2004.

Hamzah, "Hubungan Eksekutif dengan Legislatif Daerah dan Implikasi Hukumnya", Disertasi Pascaserjana UNHAS, 2008.

web.site.http/m.hariansib.com. diakses, senin 19 April 2010.

UU Dasar Negara Republik Indonesia Tahun 1945.

UU No. 32 Tahun 2004 Tentang Pemerintahan Daerah.

UU No. 12 Tahun 2008 tentang Perubahan UU No. 32 Tahun 2004 tentang Pemerintahan Daerah.

UU No. 33 Tahun 2004 tentang Perimbangan Keuangan antara Pemerintah Pusat dan Pemerintah Daerah.

UU No. 10 Tahun 2004 tentang Pembentukan Peraturan Perundang- Undangan.

UU No. 25 Tahun 2004 tentang Sistem Perencanaan Pembangunan Nasional.

Peraturan Pemerintah No. 38 Tahun 2007 tetang Pembagian Urusan Pemerintah Antara Pemerintah, Pemerintah Daerah Provinsi dan Pemerintah daerah Kabupaten/Kota.

Peraturan Pemerintah No. 79 Tahun 2005 tentang Pedoman Pembinaan dan Pengawasan Penyelenggaraan Pemerintahan Daerah.

Peraturan Pemerintah No. 6 Tahun 2008 tentang Pedoman Evaluasi Penyelenggaraan urusan Pemerintahan daerah. 